\title{
THE WARD HUNT ICE SHELF: RECENT CHANGES OF THE ICE FRONT *
}

\author{
By G. Hattersley-Smith \\ (Geophysics Section, Defence Research Board, Ottawa, Canada)
}

\begin{abstract}
Massive calving of the Ward Hunt Ice Shelf, northern Ellesmere Island, occurred between August I $_{96}$ I and April 1962. An estimated $596 \mathrm{~km}^{2}$ of ice shelf with a volume of 18 to $24 \mathrm{~km} .^{3} \mathrm{became}$ detached to form ice islands, five of which are very large with areas ranging from 70 to $140 \mathrm{~km} .^{2}$. The fracture pattern and the subsequent drift of these ice islands are discussed.
\end{abstract}

RÉsumé. Un vêlage massif de l'Ice Shelf de Ward Hunt dans la partie nord de l'île Ellesmere s'est produit d'août I96I à avril $\mathrm{I} 962$. Environ $596 \mathrm{~km}^{2}$ de l'ice shelf représentant un volume de 18 à $24 \mathrm{~km}^{3}$ se sont morcelés en îles de glace dont cinq sont très grandes, car elles ont des surfaces allant de 70 a $140 \mathrm{~km}^{2}$. La forme de cette cassure et la dérive subséquente de ces îles de glace sont discutées plus longuement.

Zusammenfassung. Eine massive Kalbung fand am Ward Hunt Ice Shelf, nördliches Ellesmere Island zwischen August 1961 und April 1962 statt. Vom Eis-Schelf löste sich ein Bereich von $596 \mathrm{~km}^{2}$ Fläche und einem Volumen von $18-24 \mathrm{~km}^{3} \mathrm{ab}$, um Eisinseln zu bilden. Fünf von ihnen sind sehr gross mit Arealen von 70-1 $40 \mathrm{~km}^{2}$. Die Bruchstrukturen und die anschliessende Drift dieser Eisinseln werden diskutiert.

\section{INTRODUCTION}

Air photographic reconnaissances by 408 Squadron of the Royal Canadian Air Force show an extensive break-up of the Ward Hunt Ice Shelf to form ice islands between August I96 I and April ig62. The Ward Hunt Ice Shelf is the largest of four main ice shelves off the north coast of Ellesmere Island; the other ice shelves are named M'Clintock, Ayles and Milne after the fiords where they occur, and, unlike the Ward Hunt Ice Shelf, they are not known to have extended seaward beyond the line of the outer coast. (The name "Ellesmere Ice Shelf", which has never been officially accepted, has been used loosely to refer to any or all of these ice shelves and lesser fragments of ice shelf which persist along the coast; it has most often been used with specific reference to the Ward Hunt Ice Shelf.) Known and inferred changes in the extent of ice shelves off this coast during recent decades are briefly reviewed below; there follows an account of the latest change and of the drift of the new ice islands, with comments based on a study of the air photographs and on limited ground observations.

The Ice Front off the North Coast of Ellesmere Island, i 876-ig6i

The Ward Hunt Ice Shelf extended 6 to $8 \mathrm{~km}$. to seaward off Markham Bay, and along the Cape Columbia shore as far east as Cape Aldrich, during the time of the British Arctic Expedition, 1875-76, and of the Peary Expeditions, I905-06 and 1908-09. The ice shelf in this area broke away probably in the year 1946, leaving a re-entrant in the ice front north of Cape Nares (Fig. I). The resulting large ice island, measuring about 2 I by $9 \mathrm{~km}$., at first drifted eastward, for in August 1947 it was photographed spanning the meridians of Cape Aldrich and Good Point, at distances of 7 and $10 \mathrm{~km}$. respectively from those points, with its long axis in a roughly west-north-west-east-north-east direction. The subsequent fate of this ice island is unknown (Koenig and others, I952, p. 76-77). It has been shown that the extent of the Ward Hunt Ice Shelf between long. $72^{\circ}$ and $77 \cdot 5^{\circ}$ W. was virtually the same in 1954 as it was in 1906 (Bushnell, 1956). Other changes in the extent of ice shelf before 1961 can only be inferred from the accounts of Aldrich of the British Arctic Expedition and of Peary. Thus it seems probable that in 1876 and in 1906 ice shelf covered at least the outer part of Yelverton Bay, ${ }_{1} 50 \mathrm{~km}$. west of Ward Hunt Island, and that break-up occurred between 1906 and 1947 , for in the latter year air photographs of that bay show only the remnants of ice shelf, still present at least as recently as 1959 , and a few ice islands frozen into the pack ice. Yelverton Bay is large enough to have been the birth-place of the ice island T-3 (Crary, I96o,

* Published by permission of the Chairman, Defence Research Board, Canada. 


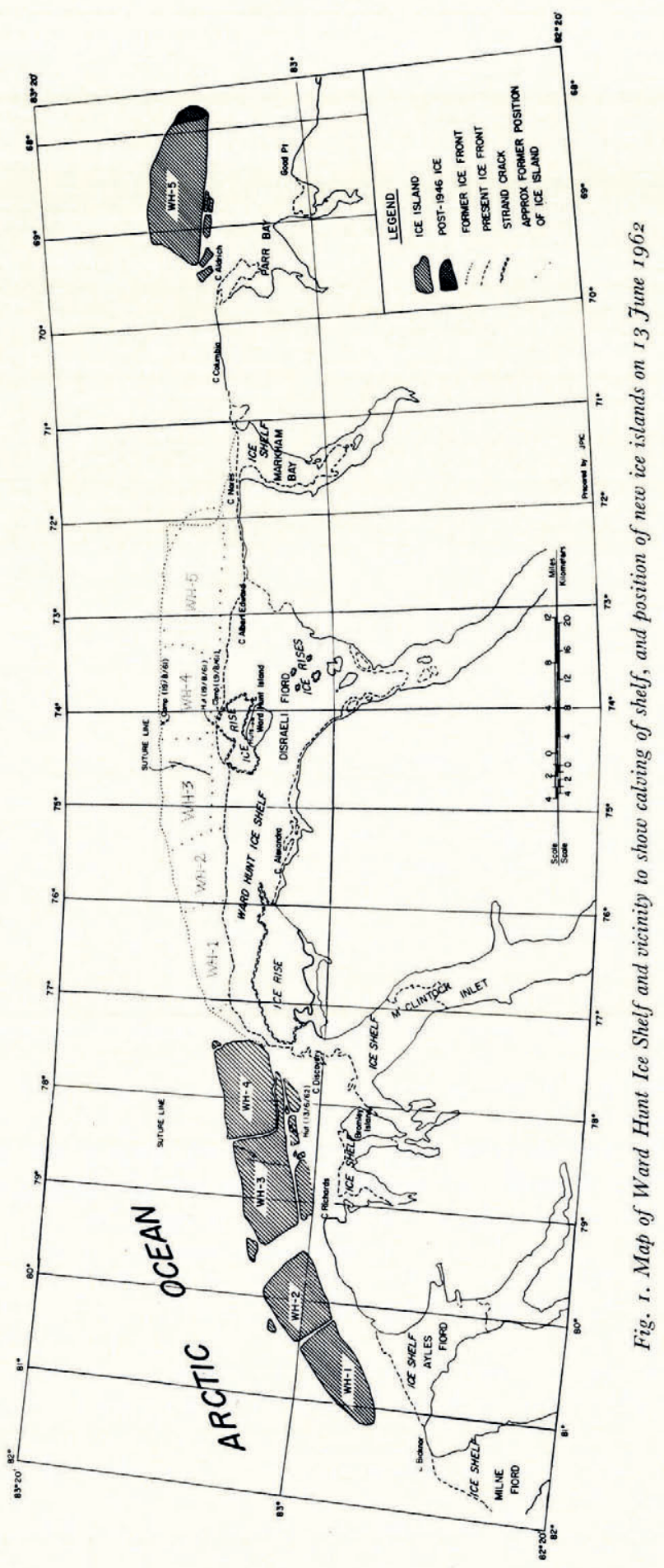


p. 44-45). There are also indications from air photographs of some disintegration of ice shelf in recent years between the north end of Bromley Island and the ice-free land at Cape Discovery, and also immediately to the west of Yelverton Bay (Hattersley-Smith, ig62, p. II-19).

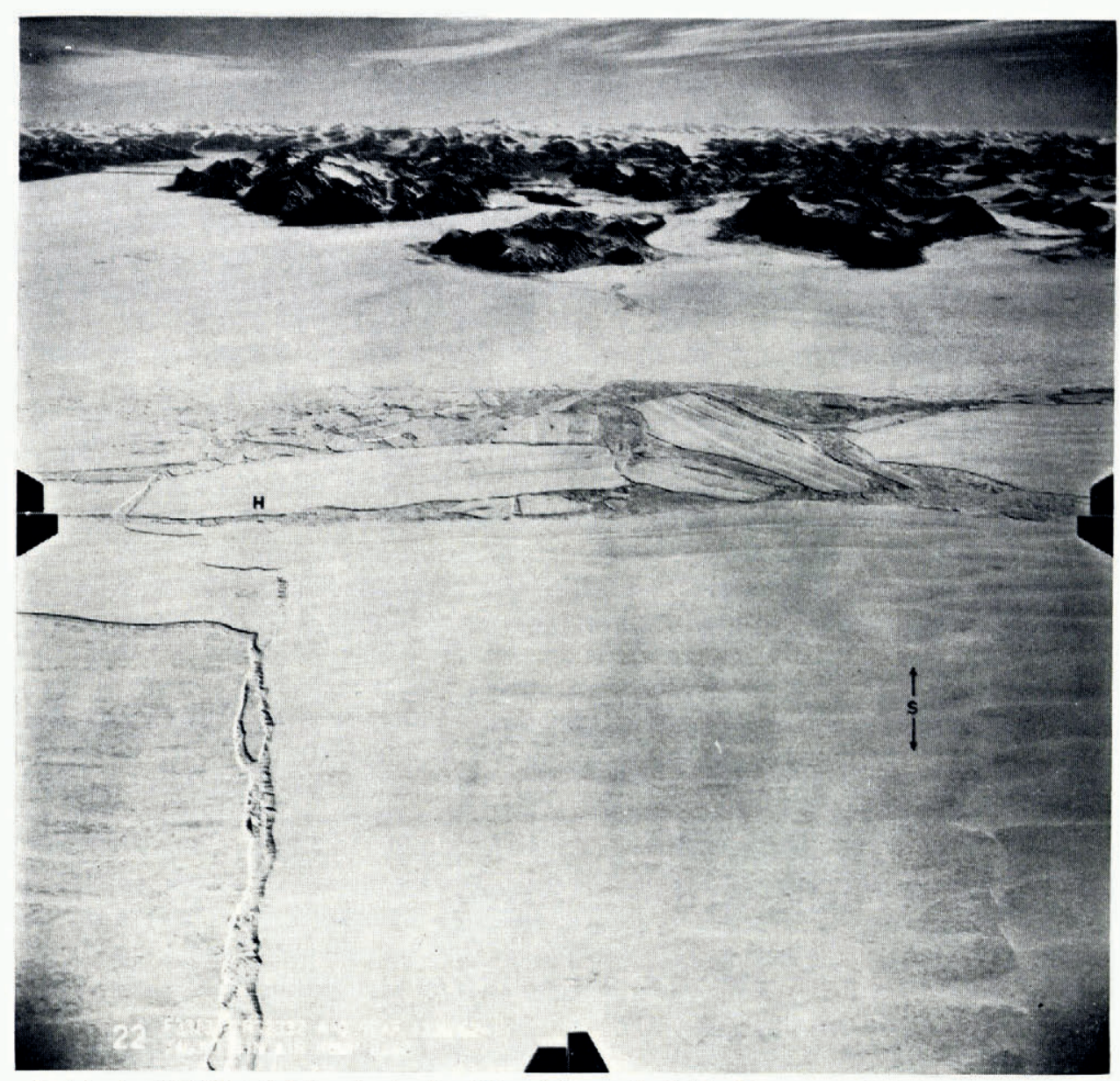

Fig. 2. Ice islands off M'Clintock Inlet, showing hut $(H)$ and "suture line" (S). Photograph: R.C.A.F., I3 June 1962, from $7,400 \mathrm{ft}$. $(2,255 \mathrm{~m}$.

Calving from the Ward Hunt Ice Shelf, i $961-62$

No changes in the extent of the ice shelf were evident in air photographs of I9 August I96 I. The dramatic calving from the Ward Hunt Ice Shelf in the winter of $196 \mathrm{I}-62$ was first indicated when a hut was observed on a small ice island off the mouth of M'Clintock Inlet, $8 \mathrm{~km}$. north of Bromley Island (Figs. I and 2). The observation was made on i 8 April ig62 during a reconnaissance flight by 408 Squadron, R.C.A.F. This hut had been sited in the I 960 summer near the southern edge of the ice shelf, $400 \mathrm{~m}$. north of the Ward Hunt ice rise. The hut was used as living quarters by a small meteorological group of the Arctic Institute of North America's field party, sponsored by the Air Force Cambridge Research Center. The main base of this party was on the north side of the ice-free part of Ward Hunt Island; there was another auxiliary camp on the northern edge of the ice rise (Fig. I; Lister, 1962). 
On 27 May 1962 air photographs by 408 Squadron confirmed that there had been extensive calving of the ice shelf as far east as Ward Hunt Island. The full extent of calving along the entire ice front to Markham Bay did not become apparent until a flight along the coast from Cape Richards eastward by an Otter aircraft on io June. The aircraft was under Defence Research Board charter, and was piloted by Mr. R. Dublicquy, who was accompanied by the author; landings were made at each of the three camps mentioned above. It was evident that five large ice islands had been formed and many small ice islands (or slivers of ice shelf). The largest ice island, situated on ro June about ro $\mathrm{km}$. north of Good Point, was reported by Mr. Dublicquy to have drifted about $25 \mathrm{~km}$. eastward since he had flown over it ten days previously. On a further reconnaissance mission on I3 June, 408 Squadron obtained trimetrogon photographs from a height of $2,255 \mathrm{~m}$. along the coast from Cape Bicknor to Good Point. From these photographs a map of the greatly reduced Ward Hunt Ice Shelf has been prepared under the direction of Major C. I. Taggart (Fig. I). It is apparent that about $596 \mathrm{~km} .^{2}$ of ice shelf has been calved; if a mean thickness of 30 to $40 \mathrm{~m}$. is assumed for this part of the ice shelf, then 18 to $24 \mathrm{~km} .{ }^{3}$ of ice has been lost. The map shows the distribution on 13 June of all ice islands with an area of more than $5 \mathrm{~km}^{2}$; a few smaller ice islands are also shown. The five largest ice islands have been provisionally named wH- , 2, 3, 4 and 5 .

The ice shelf calved right back to the grounded ice (ice rise) at Ward Hunt Island (Fig. 3), but still extends for about $3 \mathrm{~km}$. to seaward from the Cape Discovery ice rise. The new ice front in between has only minor indentations; it tends to run parallel to the surface ridges and troughs. It is assumed that there was not a line but rather a narrow zone of fracture along the new front, in order to account for the resultant large number of small ice islands (or slivers of ice shelf) of a few hundred to a few thousand square metres in area. Evidently there was also a second, but comparatively minor, fracture zone immediately to the north of Ward Hunt Island at a distance of about $\mathrm{I} \mathrm{km}$. from the ice rise. Ice islands resulting from both fractures moved westwards en masse to block off the mouths of M'Clintock Inlet and Ayles Fiord, but preserved roughly the original disposition they had when they formed part of the ice shelf.

Three major north-south fractures have produced the four large ice islands wH-I, 2, 3 and 4 from a section of the ice shelf 5 to $8 \mathrm{~km}$. wide; in the air photographs of 13 June, the easternmost of these fractures had barely opened. In the same air photographs the ice island wH-4 abutted the ice shelf off Cape Discovery; its original position north of Ward Hunt Island is apparent from the distinctive north-south "suture line" which cuts across the ridges and troughs (Fig. 3). This line, possibly marking a former limit of grounding, used to run north from the western extremity of the Ward Hunt ice rise. wH- 3 and 4 together extend for $16 \mathrm{~km}$. eastward of the "suture line", showing that the ice shelf as far east as the meridian of long. $73^{\circ} 3 \mathrm{o}^{\prime} \mathrm{W}$. moved westwards (Fig. I).

The inner part of the ice shelf close to Ward Hunt Island was broken into several relatively small ice islands, on one of which, about $3 \mathrm{~km}$. long and less than $\mathrm{I} \mathrm{km}$. wide, the hut mentioned above is situated. It is clear from the air photographs of 13 June (Fig. 2) that the latter was formerly joined to $\mathrm{wH}_{-3}$, in relation to which the photographs show a westward drift of about $400 \mathrm{~m}$. From the northernmost point of the Ward Hunt ice rise, where the Arctic Institute's abandoned station is situated, and for about $\mathrm{I} \mathrm{km}$. on either side, the new fracture line appears to follow the strand crack. Further east and west, ice shelf, whose ridges and troughs peter out against the ice rise, borders the pack ice (Fig. 3).

East of Ward Hunt Island the ice front now extends from the northern tip of the Ward Hunt ice rise to a point about $\mathrm{I} \cdot 5 \mathrm{~km}$. north-west of Cape Albert Edward, whence it continues in an easterly direction to the mouth of Markham Bay. The ice front has a somewhat sinuous outline, following in general the direction of the ridges and troughs but occasionally cutting across as many as four adjacent ridges. Off Cape Albert Edward there is an embayment in the ice front $\mathrm{I} \cdot 5 \mathrm{~km}$. deep, containing (on $\mathrm{I}_{3} \mathrm{June}$ ) detached fragments of the ice shelf still almost in situ. Visual observations on ro June suggested that a narrow strip of ice shelf remains 


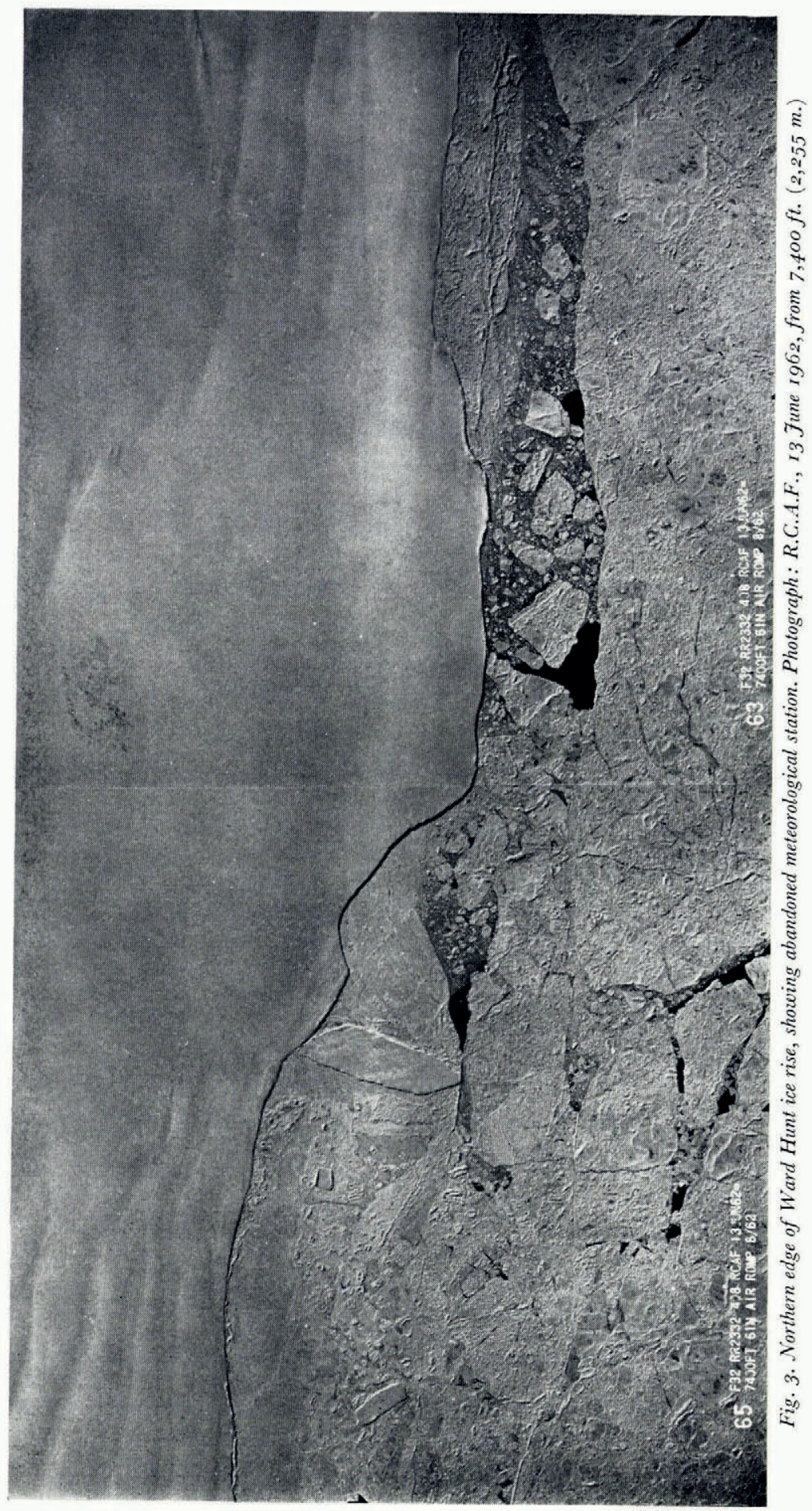


along the Cape Albert Edward-Cape Nares shore, but cloud unfortunately prevented air photography of this shore on 13 June. The major proportion of the ice shelf which broke away in this area to the east of Ward Hunt Island is preserved as a single, large ice island WH- 5 . An unusual feature of the island proves this. The air photographs show, $1 \cdot 7 \mathrm{~km}$. from the eastern edge of the island, the original north-south fracture line along which the ice shelf calved in about the year 1946 . To the east of this line the less thick ice, formed since 1946 , is readily distinguished from the thicker, much older ice to the west; the different surface appearance on the less thick ice is due to the closer spacing of the surface undulations, and to

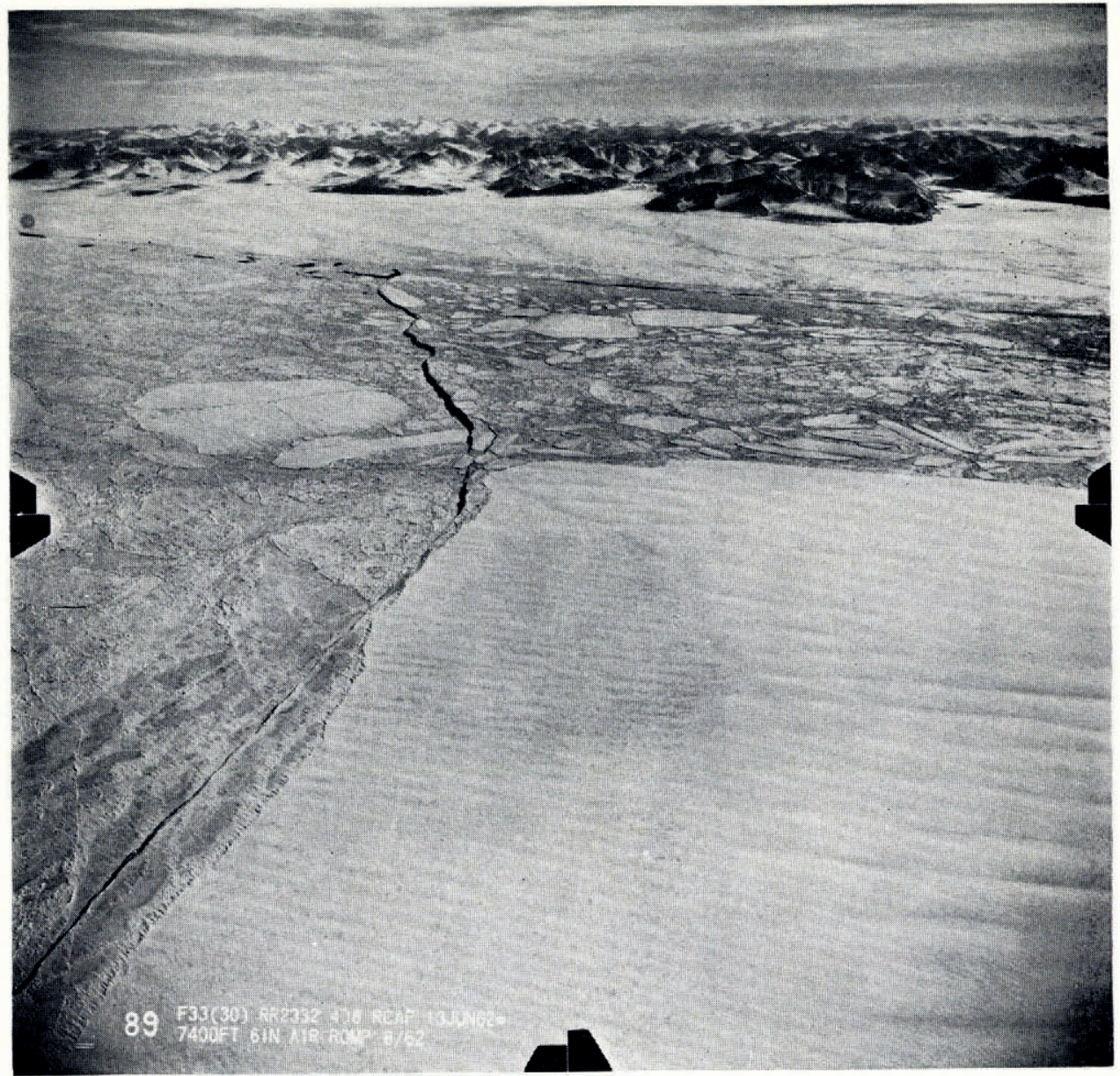

Fig. 4. Part of large ice island, wH-5, off Good Point, showing the "post-1946" ice of the former Markham Bay re-entrant. Photograph: R.C.A.F., I3 June 1962 , from 7,400 ft. (2,255 m.)

the fact that the snow had already started melting (on 13 June), giving it a darker hue than the unmelted snow on the thicker ice (Fig. 4). This "post-1 946 " ice formed over the Markham Bay re-entrant and is probably not more than about $10 \mathrm{~m}$. thick; it appears to have remained attached to the new ice island largely because of a tongue of thicker ice which wraps around its southern end and which formerly formed a part of the ice shelf $5 \mathrm{~km}$. north-west of Cape Nares. The rest of the re-entrant ice has been detached in smaller pieces. The dimensions of 
wH- 5 indicate that it formerly constituted a strip of ice shelf $8 \mathrm{~km}$. wide which calved along a roughly north-south line $5 \mathrm{~km}$. east of Ward Hunt Island. South of where wH- 5 broke away there was fragmentation of the ice shelf for about another $\mathrm{I} \cdot 5 \mathrm{~km}$. towards the shore; the resulting ice islands probably moved eastwards, for there are many small ice islands in the vicinity of Cape Aldrich.

\section{Size of New Ice Islands}

The approximate sizes of the larger of the new ice islands have been computed from the map (Fig. I), and are shown in Table I in relation to the total area of ice shelf calved and to the area of ice shelf now represented by ice islands (or slivers of ice shelf) too small to be shown on the map. Allowance is made for the fact that the re-entrant ("post-1946") ice was not regarded as part of the ice shelf proper. Figure I shows roughly the way in which the larger of the new ice islands fitted into the original ice shelf.

\begin{tabular}{|c|c|c|}
\hline able I. Ige Island Areas Compared with & $\begin{array}{r}\text { CALVED AREA or } \\
\text { Area } \mathrm{k}\end{array}$ & \\
\hline \multicolumn{2}{|l|}{ Calved portion of ice shelf } & $59^{6}$ \\
\hline $\begin{array}{l}\text { WH-1 } \\
\text { WH-2 }\end{array}$ & $63 \cdot 5$ & \\
\hline $\begin{array}{l}\text { WH-2 } \\
\text { WH-3 }\end{array}$ & $\begin{array}{l}00 \\
105\end{array}$ & \\
\hline WH-4 & 93 & \\
\hline \multirow{2}{*}{$\begin{array}{l}\text { wH-5 (old ice plus "post-1 } 946 \text { " ice) } \\
\text { Other ice islands more than } 5 \mathrm{~km} .{ }^{2} \text { in area } \\
\text { (plus a few others shown on map) }\end{array}$} & $133+6 \cdot 5$ & \\
\hline & $43 \cdot 5$ & \\
\hline Total & $5^{16}+6 \cdot 5$ & 516 \\
\hline $\begin{array}{l}\text { Smaller ice islands (or slivers of ice shelf) } \\
\text { by difference }\end{array}$ & & 80 \\
\hline
\end{tabular}

\section{Drift of New Ige Islands}

The prevailing drift of ice in the Arctic Ocean to the north and north-west of Ward Hunt Island is known from observations on the ice island $\mathrm{T}-3$, whose movement was mainly determined by wind stresses at the surface of the ice; for practical purposes pack ice and ice island moved as an entity (Crary and Browne, I 959). During the period from I May to 2 I September 1955, T-3 drifted in a south-westerly direction at a mean rate of about $\mathrm{r} \cdot 4 \mathrm{~km}$./day from a point about $110 \mathrm{~km}$. north-west of Cape Bicknor. Unfortunately there are no data on the movement of ice within $100 \mathrm{~km}$. of the north Ellesmere coast, so that the following remarks on the drift of the new ice islands are tentative.

The most noteworthy feature of the new drift pattern is the contrary eastward movement of the ice island $\mathrm{wH}_{-} 5$, which in its initial stage can perhaps best be explained through wind action. The dominant winds on the Ward Hunt Ice Shelf are from the west and south-west, and from the east and north-east; strong winds from the north or south are most unusual (Lotz, I96r, p. 38). It is supposed that $\mathrm{WH}^{-5}$ was unable to move past Ward Hunt Island under the influence of easterly or north-easterly winds, whereas the same winds readily moved the ice islands WH-I, 2, 3, and 4 westwards past the end of the Ward Hunt Ice Shelf. The reversal of wind necessary to start the drift of wH-5 would have little effect on WH-I, 2, 3 and 4 , if they had become partially embayed to the west of Cape Discovery. It seems easier to accept this explanation of the divergent drifts than to postulate currents in opposite directions on either side of Ward Hunt Island.

Off the mouth of M'Clintock Inlet the small ice island carrying the hut appeared to have moved less than $2 \mathrm{~km}$. between 18 April and 13 June i 962, and, according to observations by Mr. A. Spector of the Gravity Division, Dominion Observatory, the south-western corner of 
wH-3 still lay within $4 \mathrm{~km}$. of Cape Richards on 30 July. If the ice islands in this area move away from the coast, they can be expected to continue their south-westerly drift. The drift of wH- 5 continues to engage special interest, for according to observations by Mr. Spector on 29 July it had moved about $20 \mathrm{~km}$. in a south-easterly direction from its position of 13 June, shown in Figure I. It was last reported 4 to $5 \mathrm{~km}$. from shore, at a distance of about I Io $\mathrm{km}$. from the entrance of Robeson Channel to the south-east. The southward drift of ice through Robeson Channel is well known; recently it has been considered responsible for the escape from the Arctic Ocean of the Russian ice floe station sP-7 (Gudkovich and Balakshin, 1962; Dunbar, in press). Although it is probable that wind caused the original separation of wH-5 from the other large new ice islands, it is necessary to take into account the likelihood of a south-easterly, long-shore drift in the approaches to the Lincoln Sea and Robeson Channel. Such drift is indeed indicated by the form of gravel spits and bars near Alert, close to the entrance of Robeson Channel, and also at Cape Aldrich. There seems to be a strong possibility that the ice island wH-5 may eventually enter Robeson Channel.

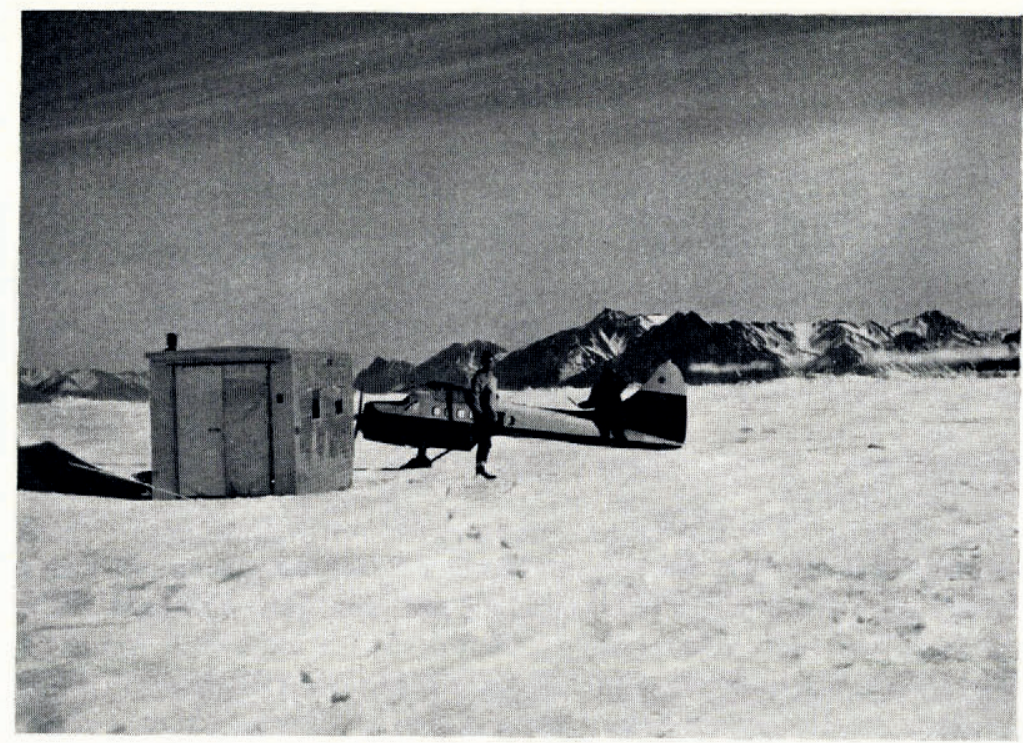

Fig. 5. Hut on small ice island off M'Clintock Inlet, ro June 1962

\section{Ground Observations}

On ro June 1962 melting on the ice shelf and ice islands had already started. Rather typical summer conditions prevailed with an air temperature of $35^{\circ} \mathrm{F}$. ( $2^{\circ} \mathrm{C}$.), easterly wind at IO-I 2 knots, and a cloud cover of $4 /$ Ioths cirrus and stratus. The following observations were made that day.

Near the hut on the small ice island north of Bromley Island (Fig. 5) snow depths on a ridge varied from I I to $29 \mathrm{~cm}$. (mean $19.5 \mathrm{~cm}$.); markings on a pole indicated that the level of melt water in a trough on 2 July 1960 was $84 \mathrm{~cm}$. above the ro June 1962 ice level; and markings on an instrument mounting $20 \mathrm{~m}$. east of the hut indicated that the present ice surface was $6 \mathrm{~cm}$. below the snow level of ig6o (date uncertain). At another pole $20 \mathrm{~m}$. west of the hut the present ice level was $36 \mathrm{~cm}$. below the snow level of 20 July ig6o, indicating that the total ice ablation for the latter part of the ig6o summer and the whole of the $196 \mathrm{I}$ summer was less than $36 \mathrm{~cm}$. The hut was situated $30 \mathrm{~m}$. from a channel filled with solid pack ice (Fig. 6), which separated the small ice island from wH-3; this channel varied in width 
from about 40 to $200 \mathrm{~m}$. A clean $4 \mathrm{~m}$. section of the ice island was exposed along the side of the channel; the usual dirt layer was clearly visible at the surface of the ridges, while in the troughs it was present beneath about $30 \mathrm{~cm}$. of lake ice. On the north side of the channel there was a pressure ridge which rose an estimated $8 \mathrm{~m}$. above sea-level as a result of the two ice islands having at some time impinged. From the freeboard of the ice islands their thickness was estimated at 30 to $40 \mathrm{~m}$. South of the ice island carrying the hut there were some scattered ice islands for a distance of $\mathrm{I}$ to $2 \mathrm{~km}$., while beyond stretched the smooth unbroken bay ice of M'Clintock Inlet.

The meteorological hut near the edge of the Ward Hunt ice rise was now only $200 \mathrm{~m}$. from a $4 \mathrm{~m}$. cliff above the moving pack ice, where there were small patches of open water (Fig. 3). Snow depths varied from i I to $39 \mathrm{~cm}$. (mean $24.5 \mathrm{~cm}$.); the snow was wet to a depth of $15 \mathrm{~cm}$., and in the deeper snow an ice layer tended to form at about this depth. Marks on a bamboo pole indicated not more than $14 \mathrm{~cm}$. of ice ablation since 2 June 1960 ; the exposed ends of buried thermocouple leads indicated $20 \mathrm{~cm}$. of ablation, and an experimentally covered area of ice now stood $10-20 \mathrm{~cm}$. above the level of the snow surface. The

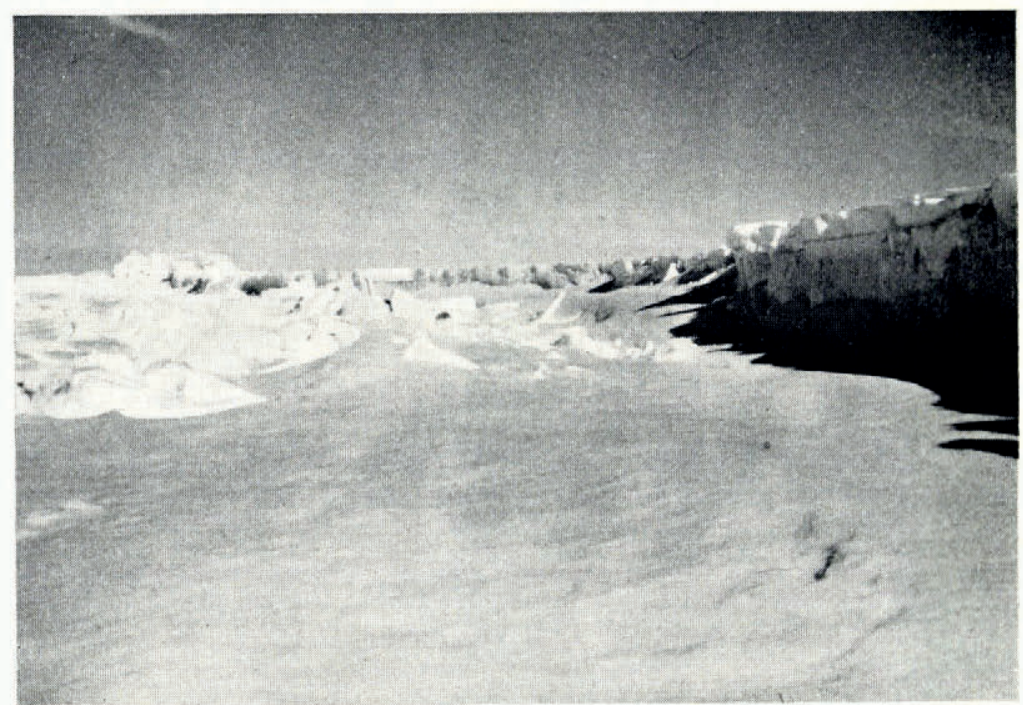

Fig. 6. Northern edge of small ice island off $M^{\prime}$ Clintock Inlet, showing $4 \mathrm{~m}$. ice cliff, ro June I962

hut had a $120 \mathrm{~cm}$. snow-drift on the west side, and stood in a shallow pool of water on the south side; there was no indication of an ice pedestal.

\section{Surveillance of New Ice Islands}

It is hoped to track at least the larger of the new ice islands, and arrangements have been made to mount suitable radar reflectors on the islands to assist tracking. Ideally the radar reflectors should be placed in distinctive patterns so that individual islands can be recognized. So far, through the co-operation of the Polar Shelf Project, under the direction of Dr. E. F. Roots, radar reflectors have been placed on wH-5. Tracking of the new ice islands may provide valuable data on rate and direction of drift in little-known parts of the Arctic Ocean, and if it should become desirable to establish a new floating station the knowledge gained will facilitate choice of a suitable site.

MS. received 24 August ${ }_{1.962}$ 


\section{REFERENCES}

Bushnell, V. C. 1956. Marvin's ice shelf journey. Arctic, Vol. 9, No. 3, p. 166-77.

Crary, A. P. 1960 . Arctic ice island and ice shelf studies. Part II. Arctic, Vol. I 3 , No. 1, p. $32-50$.

Crary, A. P., and Browne, I. M. 1959. The movement of ice in the Arctic Ocean. (In Bushnell, V.C., ed. Scientific studies at Fletcher's ice island T-3 (1952-1955). Vol. I. Bedford, Mass., Geophysics Research Directorate, U.S. Air Force Cambridge Research Center, p. 36-49. (Geophysical Research Paper No. 63.))

Dunbar, Moira. In press. The drift of "North Pole 7" after its abandonment. Canadian Geographer.

Gudkovich, Z. M., and Balakshin, L. L. 1962. Sud'ba dreyfuyushchey stantsii [Fate of a drifting station]. Priroda [Nature], I962, No. 6, p. 66-69.

Hattersley-Smith, G. 1962. Ice conditions off the north coast of Ellesmere Island. Ottawa, Defence Research Board. (Report No. Misc. G-8.)

Koenig, L. S., and others. 1952. Arctic ice islands, by L. S. Koenig, K. R. Greenaway, Moira Dunbar and G. Hattersley-Smith. Arctic, Vol. 5, No. 2, p. 67-103.

Lister, H. ${ }^{1} 962$. Heat and mass balance at the surface of the Ward Hunt Ice Shelf, r96o. Arctic Institute of North America. Research Paper No. I9.

Lotz, J. R. r96r. Analysis of meteorological and micrometeorological observations, northern Ellesmere Island, 1959. Arctic Institute of . North America. Research Paper No. 12. 